\title{
SUPPORT IN INCLUSIVE EDUCATION
}

\section{Belma Čičkušić \\ Ševala Tulumović1 \\ Selma Bakić \\ Salem Bakić}

\author{
Original scientific paper
}

Faculty of Pedagogy, University of Sarajevo, $B \& H$

Faculty of Education and Rehabilitation, University of Tuzla, $B \& H$

Elementary school "Simin Han", Tuzla, B\&H

Institute for education of persons with disabilities in mental and physical development Tuzla, $B \& H$

Received: 18.04 .2016

Accepted: 12.06 .2016

\begin{abstract}
In order for inclusive class to be successful, associates are of great help to teachers. Besides associates, teachers' specialization can be accomplished through educational seminars on the inclusion topic. However, information about inclusion, working with children with special needs, can also be found in scientific journals that offer more information on methods of working with children with special needs, didactic materials customized according to abilities of children. Aim of this research was to establish the ways of supporting teachers in their work with children with special needs. The research included 30 respondents. For needs of this research four schools in Sarajevo canton were selected: "Vladislav Skarić", "Silvija Strahimir Kranjčević", "Isak Samokovlija", and "Avdo Smailović". In all of these schools education of children with special needs is conducted. Based on the analysis, we could conclude that most of the support that teachers receive comes from educational seminars and scientific literature and least of the support comes from associates.
\end{abstract}

Keywords: children with special needs, teachers, support, inclusion.

\section{INTRODUCTION}

Inclusion is characterized by the sense of belonging, but not the mere physical belonging. Successful inclusion means involvement of all children in educational system. Teachers know how many children with special needs are struggling with school work, but unfortunately they don't know the cause for that, nor how to handle such problems. Term "special needs" means insuring appropriate legal protection, diagnostic and help from the experts (Brenan, 1985). An individual with special needs relates to a person with a professional diagnose and which has a physical or mental deficiency that substantially limits on or more major life activities (walk, sight, hearing, speech, breathing, tak- ing care of one self, performing manual tasks, learning and working) (Daniels and Stafford, 2000, according to Hadžić, Tulumović, 2008). In Canada, for more than two decades in the center of integrative vision is faith in the children and their capacities. Basically, inclusion means that a student with special educational needs overcomes the standard educational program and is included in the class of their peers with one hundred percent of school time (Idol, 1997). Work program of inclusive education according to Ainscow (1999), would be considered when it comes to students with special needs and other students would be characterized as having special educational needs.

\footnotetext{
${ }^{1}$ Correspodence to:

Ševala Tulumović, Faculty of Education and Rehabilitation, University of Tuzla

Bosnia and Herzegovina

E-mail: sevala.tulumovic@untz.ba
} 
Based on the large number of researches and good practices it can be said that the inclusion is considered as a necessary perspective for the future (Campbell, 2001). Well-established teaching process also contributes to the fulfilling of certain biological and social needs of students, the need for safety, activity, self-respect, for recognition, and contributes to the development of selfactualization of students with special needs (Bogdan Matijevic, 1997). Failure in learning along with an unfavorable educational climate and communication can have a negative impact on their emotional and social development, as it is important for each student, their educational success and acceptance in the school collective (Kavkler, 2006). Schools should be organized in a flexible manner, where teachers, students and community in general work all together towards fulfilling individual needs in order to minimize obstacles to inclusion in schools (Miles, 2002). However, if a child with special needs is not well accepted in class collective, if it shows low motivation levels towards school work, it will create a bad picture about itself and will show functional deficiency and rashness (Rispensy, 1994). Discrepancy between student's potential and educational requirements of the school does not lead to satisfactory qualitative change but it leads to unwanted changes and unsuccessful education (Prior, 1996). In order for students with special needs to have successful education process, it is necessary to approach them with appropriate individual didactic - methodic procedures (Ivančić et.al. 2002). That is accomplished through differentiation process. Differentiation process is a process where we tailor educational goals, grading methods, learning activities and teaching aids in a way that fits the needs of a child (Revell 1997). Differentiation process can be put to use if following conditions are met: active participation of children with special needs in learning process, ability to learn independently, shaping positive attitude, steering the whole school towards differentiation (Naylor et.al., 1997). In a large research in India, which was conducted on sample counting 3000 children with special needs from different parts of India, only $25 \%$ passed the class with teaching support (Singh, 2003). National institute of open education in India offers open education in which adjustments of teaching materials and individualized process of teaching is conducted (Rao et.al. 2002). Feedback shows that in some parts of India, inclusive schools and organizations that support education cover adjusted teaching materials in mother and foreign language and math, with appropriate didactic material, in fact help successful finishing of elementary education (Narayan et.al. 2006). In Brasil, in open school methodology, students create teaching materials and learning pace. They are graded on a daily basis. Teaching material is contained in their every-day life and obstacles are overcome with adjusted teaching (Bernard, 2001). In Jamaica, process of early inclusion and involvement of students with special needs in daycare centers and lower years in elementary schools is conducted. Individual educational programs application project is considered successful and offers great support to children in their every-day lives (Thorborn, 1995).

\section{AIM OF THE RESEARCH}

Aim of this research was to investigate the ways how teachers get support in their work with children with special needs.

\section{WORK METHODS}

\section{Sample}

Sample was consisted of 30 teachers from schools in Sarajevo Canton: "Vladislav Skarić", "Silvija Strahimir Kranjčević", "Isak Samokovlija", and "Avdo Smailović", where are classes with children with special needs.

\section{Instruments}

Data was collected using a questionnaire for teachers (Krulj, et al, 2003).

\section{Ways of conducting research}

Research in Sarajevo was conducted by personal interviews. Preparations have been made in all the schools involved. They are comprised of a visit to regular primary schools where discussions were held with school principals and teachers. Time, methodology and support were agreed. Teachers were given questionnaires and methods of filling were explained. Survey included all the teachers that had children with special needs in their classes. Teachers could ask for additional explanations while filling the questionnaires. Research was conducted in four regular elementary schools in Sarajevo Canton: "Vladislav Skarić", "Silvija Strahimir Kranjčević", "Isak Samokovlija" and "Avdo Smailović". Thirty teachers were interviewed with the questionnaire for teachers, where they were asked questions about the ways and methods of support they get while working with children with special needs and how helpful is that support in terms of making their work easier. 


\section{Data processing methods}

Data processing and graphic display obtained results were done Microsoft Excel 2000.

\section{RESULTS}

On Figure 1 support for inclusive teachers from associates is shown.

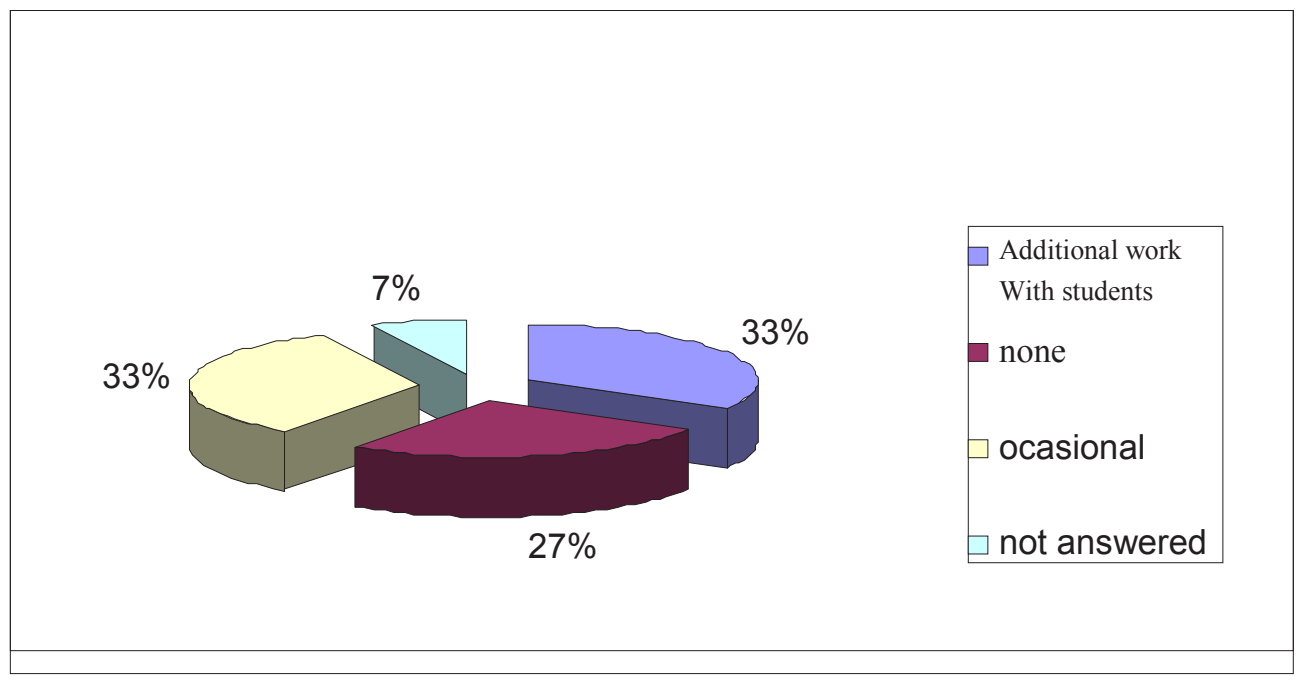

Figure 1. Graphic display of support

On Figure 1, we can see that 33\% of the respondents answered that associates provide them with help through educations for teachers and additional work with children - equally, $7 \%$ of the respondents have not given any answer to this question and $27 \%$ of the respondents answered that they do not get any support and they have no cooperation with associates. Also, 33\% of the respondents answered that they get support from associates occasionally.

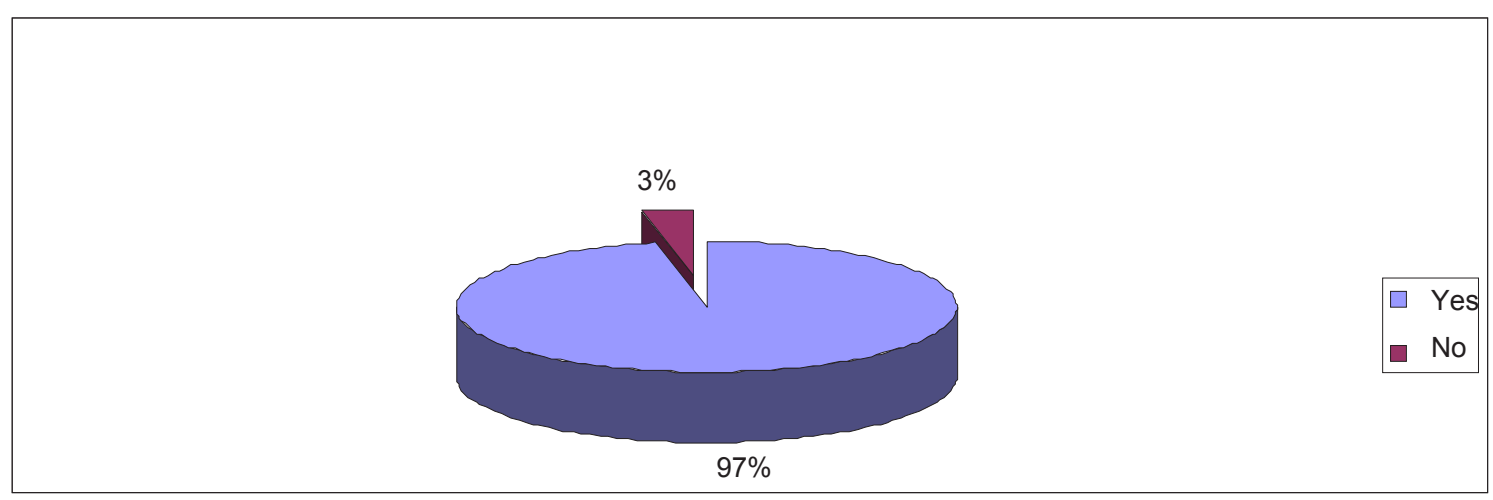

Figure 2. - Graphic display of support by educations

On Figure 2 we can see the percentage of specialization of teachers by educational seminars.

Based on this graphic display, we can see that $97 \%$ of the respondents attend seminars regularly, and only $3 \%$ does not attend seminars on the topic of inclusive education of children with special needs. 


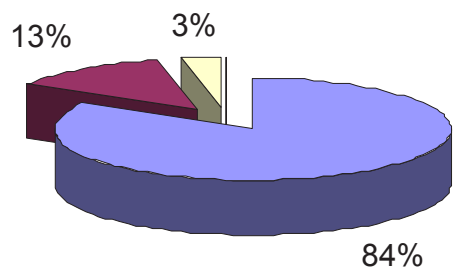

Figure 3. Graphic display of number of seminars attendance

Further, research with aim to establish how often teachers attend seminars on topics of inclusion of children with special needs in regular schools is conducted. Data describing that is show on the image 3, where we can see that out of all respondents, 84\% of them attended seminars 5 times. Considering that inclusion process has began in year 2004, this number should be higher. While $13 \%$ of the respondents answered that they attended 10 and only 3\% of the respondents attended seminars more than 10 times.

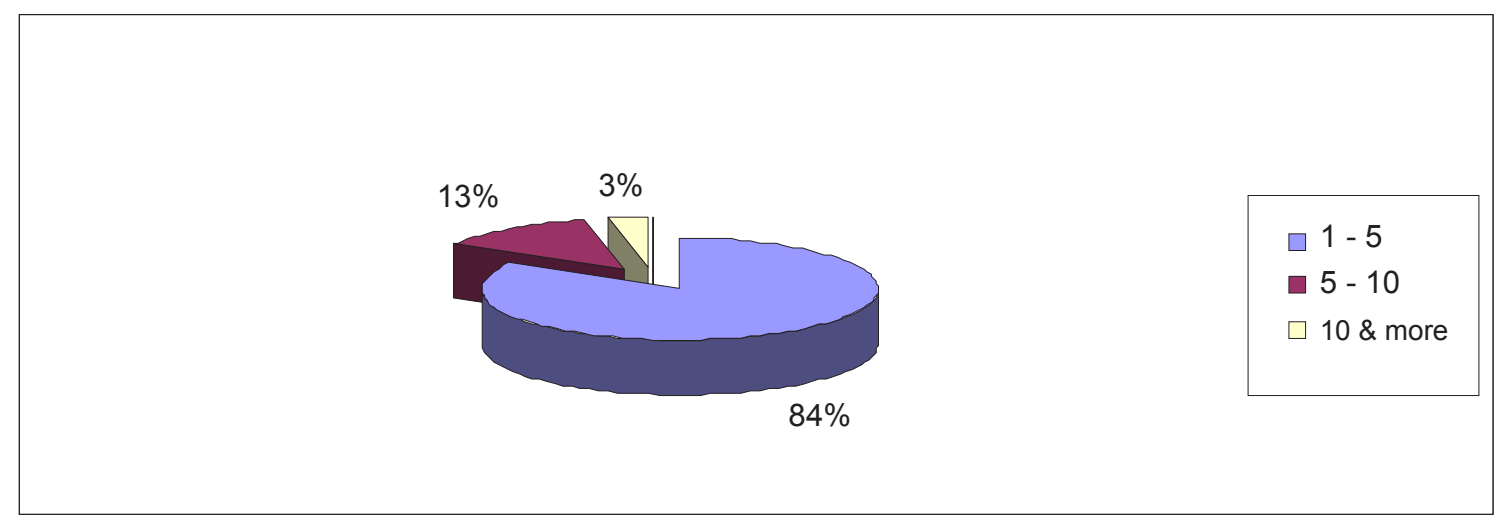

Figure 4. Graphic display of successfulness of inclusion seminars

On Figure 4 successfulness of seminars attendance is shown. From the graph we can see that $3 \%$ of the respondents claimed that they had no use of attending seminars, $3 \%$ of the respondents claimed that they had some success but rarely. Majority of the respondents, $51 \%$ of them, answered that they had benefits of at- tending seminars sometimes. Rest of the respondents, $23 \%$ of them answered that they often have benefit of attending seminars on the topics of inclusion, and 20 percent of the respondents answered that they always had benefit from attending seminars on the topics of inclusion.

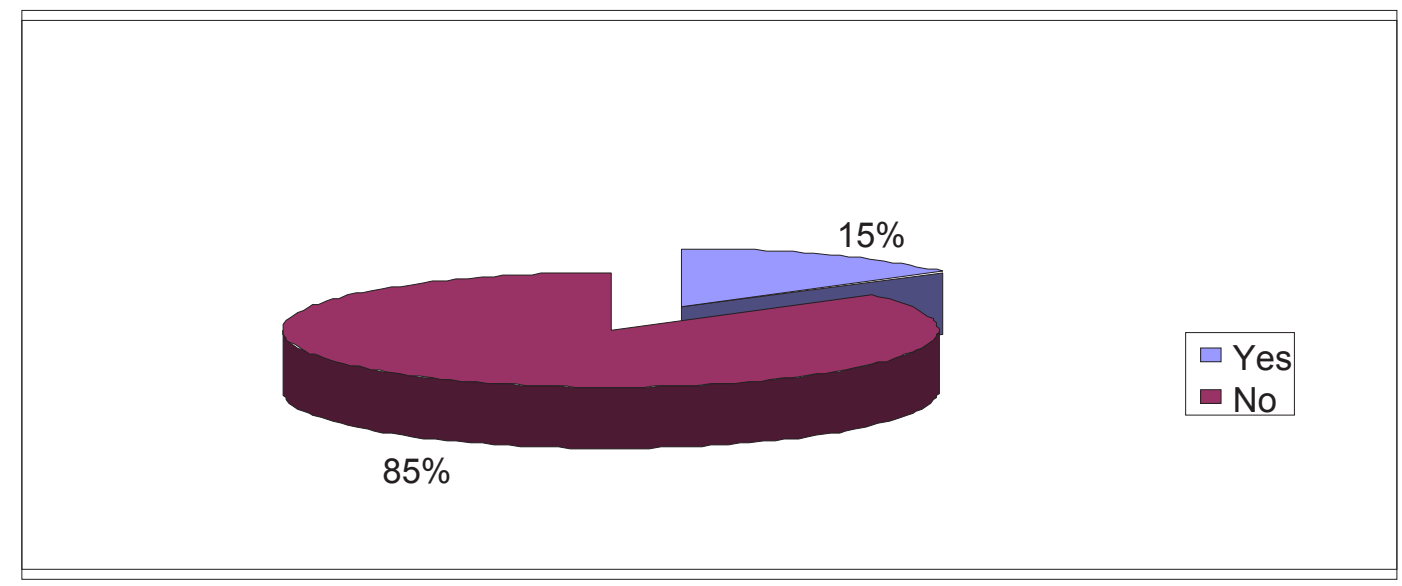

Figure 5. Graphical display of subscriptions of schools to journals on inclusive education 
On Figure 5 we can se percent of subscribed schools to scientific journals that deal with the topics of inclusive education of children with special needs. From the graph, we can see that $85 \%$ of the respondents answered that the school is not subscribed to such a journal, and only $15 \%$ of the respondents claimed that the school is subscribed to scientific journal that deal with the topic of inclusive education of children with special needs.

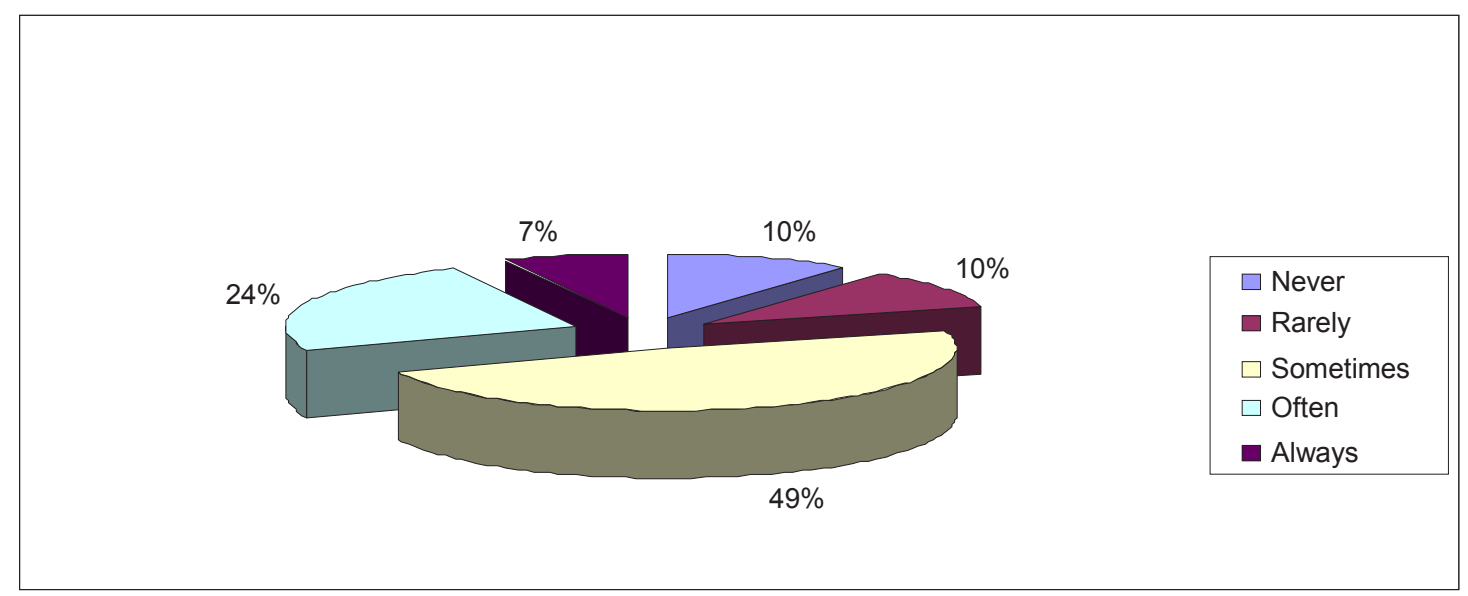

Figure 6. Graphic display of scientific journals' helpfulness

On Figure 6, successfulness of scientific journals in practical work of teachers is shown.

We can see that $24 \%$ of the respondents answered that journals were often successful in helping them in practical work, journals were always helpful in cases of $7 \%$ of the respondents, rarely successful in cases of $10 \%$ of the respondents, also $10 \%$ of the respondents answered that they had no practical use of journals, and majority respondents answered that scientific journals were sometimes useful in their practical work.

\section{DISCUSSION}

Based on obtained results, we can conclude that seminars are one of the ways for teachers to specialize and that is teachers' legal obligation. Many teachers complain about additional hours in schools or attending seminars and they expect to get paid for time invested. On the contrary, they should consider the possibility of continuing their education as a privilege that will acquire them knowledge and techniques that will allow them to reduce their stress levels and to enhance education experience for students. Attending seminars allows teachers to be up to date with their field of influence and study, strengthening their enthusiasm and professionalism. On their return to the school, teachers should be encouraged to share their knowledge with their colleagues, so they can too, adopt new concepts and methods. These answers remind us to data from literature, where we can find that teachers often expect to get prepared recipes on how to work with children with special needs. That is not possible, because every child is an individual, and therefore seminars can only offer information on methods of working with children where teacher has to adopt different methods on each child. However, the question of competence of presenters on seminars also emerges. Do the presenters modify their lecture to the group they are lecturing, do they talk only about theory or they also speak about practical approach, where every teacher has to make modifications necessary, in order for his class to reach their maximum potential. Scientific journals are very important source of information on methods of working with children with special needs. Research conducted under sponsorship of UNESCO in Nicaragua was marked as very successful by the teachers who underwent education on individual educational programs for children with special needs (Engelbrecht et.al 1999). Similar research was conducted in Maputo province in Mozambique, where competition on inclusive education was organized. Teachers were asked to submit their reports about strategies on working with children with special needs. Commission marked their work with positive grade, because they were using adjusted programs for working with children with special needs (Lehtomaki, 2002). Educational success and acceptance of students with special needs is greatly influenced by the teacher. In doing that teacher needs support from parents and cooperation with other teachers who work with the child (Stančić et.al. 1999). 
Teacher is an important subject of educational integration, and therefore he needs to be supplied with support and council from special education teacher as well as additional education for accepting and working with children with special needs (Stančić et.al. 2001). Open school program allows students to be involved in creating content and ways of learning. Students are encouraged to adopt knowledge through spontaneity and stimulating environment. Basic method is problem solving learning method. Role of the teacher flows through phase of planning, preparation and organizing learning environment that will allow individual learning for students and integration among the students is open (Paivi, 2002). This type of research was also conducted in India, under sponsorship of Ministry of Development and human resources, and only $3-4 \%$ of children with special needs have access to education with or without support in education. It is estimated that around 60.000 children are attending 15.000 schools but rate of children leaving schools is also very high (Narayan, et.al. 2006).

\section{CONCLUSIONS}

Based on obtained research results it can be concluded that teachers get support in their work in form of education and specialization, reading scientific journals that deal with the topic of inclusion of children with special needs. While just a few inclusive teachers get support from associates. We can also conclude that teacher is left to deal with class problems alone. The fact is that greatest consequences do not affect managers nor teachers but children. In educational process, attending seminars, all teachers from the sample were included. But, in the process of professional development should also be included pedagogues, principals, parents and teachers, all people who work with children with special needs. School will be in a situation to realize its basic tasks if it is filled with competent professionals and material conditions for normal functioning.

\section{REFERENCES}

Ainscow, M. (1999). Understanding the Development of Inclusive Schools, London: Falmer.

Brennan, W. (1985). Cuurricllium and special neds in: Wiliams $P$. Young Peds Curriculum for special needs, Philadelphia, open University pres.

Bogdan Matijević,M. (1997). Didaktika, Zagreb: Školska knjiga.

Bernard, A.K. (2001). Education for All and Children who are Excluded. Pariz.

Campbel LJ. (2001). Creating our camon future, Edukating for uniti in diversity, Unesko publishing / Berghalin books, Paris, New York, Oxsfodr.
Egelbrecht, L., Gren, S. (1999). Inclusive education in action in South Africa. Pretoria: J.L. P.177.

Hadžić, S., Tulumović, Š. (2008) Efekti prilagođenih programa iz bosanskog, hrvatskog i srpskog jezika i književnosti drugog razreda osnovne škole. Didaktički putokazičasopis za nastavnu teoriju i praksu, (47): 63-68.

Idol, L. (1997). Key questions related to bulding collaboratixe and inclusive schools. Jurnal of Learning Disabilities, 30-4.

Ivančić, Đ., Stančić , Z. (2002). Didaktičko-metodički aspekti rada sa učenicima sa posebnim potrebama: Do prihvatanja zajedno: integracija djece sa posebnim potrebama, priručnik za učitelje, Zagreb.

Kavkler, M . (2006). Odgoj i obrazovanje djece sa posebnim potrebama http: // www, see - educoop. net / education 07/ 02 / 2004.

Lehtomaki, E. (2002). Inclusive Schools in Mozambique. EENET. Issue (http//.www.eenet.org.uk/theory_practice/integrat.shtml.

Miles, M. (2002). The role of specijal education in information based rehabilitation. Europen Jurnal of Specijal Needs Education, 4 (2): 111-118.

Narayan,J., Rao, G.L. (2006). Utilising existing resources for inclusive education of children with disabilities in Indija: Asia Pacific Disability Rehabilitacion Journal, 17(1): 87-93.

Naylor, S., Keogh, B. (1997). Differentation in teaching science. Teaching Science in the primary scholl. A praactical source book of teaching strategies. Edited by Alan Cross and Gill Peet. Plymout, North House Publishers.

Paivi, A. (2002). Theories of curriculum and teaching (Plan for lecturing).

Prior, M. (1996). Understanding Specific Leaning Difficlties. Psychology Press. UK.

Rispensy, J. (1994). Rethinking the course of integration: What can we learn from the past? New Persptives in Special Education. Routledge. London.

Revell, R. (1997). Day to day dyfferentation. QMS-Question of Math and Science. http://www.danidavforum.um.dk/ menu/Themes/Education/Tool/Box/Good Practices/)

Rao,S.,Nrayan,J. (2002). Aarambh-Inclusive package for preschool education. Hyderabad:UNICEFNIMH.(httpl://www.unesco.org./education/efa/ed/forall/background/jomtien declaration. Shtml).

Singh, J.P. (2003). Disability Status India. New Delhi: Rehabilitation Council of India.

Stančić, Z., Ivančić,Đ. (1999). Nastavnik čimbenik kvalitete u odgoju i obrazovanju učenika usporenog kognitivnog razvoja. U: Nastavnik čimbenik kvalitete u odgoju $i$ obrazovanju, Filozofski fakultet, Rijeka, 469 - 482.

Stančić,Z., Kiš Glavaš, L., Igrić, LJ.(2001). Stavovi učitelja prema poučavanju kao deferminautna njihove spremnosti za dodatno stručno usavršavanje. Hrvatska revija za rehabilitacijska istraživanja, 37 (2): 157 - 172.

Thorborn, M. (1995). Community Based Early Intervention in Jamaica: A Home based Model Incorporating Parents of Children with Disabilites. In Special Education in Latin America, 61-72. 